\title{
The Migrant Metaphor Within Radical Italian Thought
}

\section{INGRID M HOOFD}

The general ideology of global development is racist paternalism; its general economics capital-intensive investment; its broad politics ... the subaltern as the rhetoric of their protest.

Gayatri Spivak ${ }^{1}$

Let us then, for the moment at least, arrest the understandable need to fix and diagnose the identity of the most deserving marginal. Let us also suspend the mood of self-congratulation as saviours of marginality.

Gayatri Spivak²

The lives and living conditions of refugees and migrants have gained ground as a legitimate source of politicised resistance or research in various European radical, activist and intellectual circles. Activist groups such as Kein Mensch ist Illegal, AG3F (Anti-Racist Group for Free Flooding), Autonoom Centrum and the NoBorder network in Europe, ${ }^{3}$ as well as xborder, BaxterWatch and Woomera2002 in Australia, ${ }^{4}$ have proliferated. At the same time, there has been an increasing focus within European Union (EU) and International Office of Migration (IOM) on what these policy makers tend to call 'effectively containing the migrant issue'. Simultaneously, an increase of research and a shifting of theoretical paradigms focusing on 
migration and refugee issues can be seen within Western, and especially European, academic and non-academic social sciences and humanities research. In particular, since 1995 there has been a rise in organisations, departments and institutions (like the European Research Centre on Migration and Ethnic Relations) that deal with the policing, critiquing of policing and researching of migratory flows within the EU. The number of worldwide studies on migration issues has more than tripled in this period. ${ }^{5}$ This recent upsurge, I will argue, is symptomatic of certain Western desires and fears in the information age, and has caused the image of the migrant to 'travel' through left-wing academic and activist circles in most peculiar ways. As an immediate example of the current obsession with the migrant in academia and activism in both Europe and Australia, 'The Italian Effect' conference tellingly had as one of its main themes 'the multitude, refugees and globalisation'.

We could effectively locate the strands of 'radical Italian thought' that seek to incorporate migrant issues within their conceptual framework of liberatory struggles as, in a sense, a hybrid praxis, residing on the borders of academic humanities and activist or alter-globalist knowledge construction. It is therefore important to keep these radical Italian thinkers under close observation, because of their close ties to and ongoing influence on both academic and alterglobalist activist practices, like the European and World Social Forums. And I believe a critique of the migrant appropriation in Italian thought becomes ever more urgent, because the Eurocentrism that inhabits this appropriation is perpetually ignored. Most activist and academic endeavours around migration are set up with the intention of combating or resisting the racist, xenophobic and otherwise exclusionary EU or IOM policies. This intention is both valid and valuable, because EU and IOM policies indeed falsely enforce the dangerous myth that migration from certain countries and groups is a 'threat' in need of containment, thereby effectively constituting the migrant or refugee as a mere object or problem. I will however claim that the NoBorder activisms and Italian philosophies are also highly complicit in the ongoing fortification of the EU and the West, and of the West's subsequent global hegemonic spread through Eurocentric discourses and technologies. I will show that many radical Italian writings, through a metaphorisation of the 'migrant' or 'refugee', supplement the alter-globalisation movement in effectively reproducing the Eurocentric fantasy of the Enlightenment subject as the ultimate centre for social change, just as much as those despised EU policies do. I will do so by pointing out that this migrant metaphor functions primarily as a tool to make possible the claim for some sort of hegemonic 'unification of struggles' in 'the new world order' by these radical Italian thinkers. They will be shown to do so through a doubly romanticising move, leading to both the reproduction of the migrant or refugee as a heroic figure and the acting out of an unfinishable desire for communal self-identification with the migrant, through claims that $\mathrm{s} /$ he embodies the transcendental fantasy of the total subsumption of boundaries.

We will see that this utopian fantasy of a subject transgressing borders sits eerily well with the promises and faculties of the new communication and transportation technologies that 
Western global hegemony needs and endorses, as well as with the rather Christian selfconstruction of many Western academics and activists as 'saviours of marginality'. The depiction of these new technologies within radical Italian thought will appear to be congruously in step with much of the American cyberhappy and neo-liberal discourses, which makes one wonder how 'radical' this strand of thought really is. In fact, its supposed radicality can be seen as a modernist trick to pretend a break with European modernity, while actually hiding from scrutiny a repetition of Eurocentrism. The humanist idea of resistance, which mystifies resistance as 'authentic' in its force and hence outside power structures, forgets that resistance is in fact always using and inscribed in power relations itself. It is this ultimately modernist notion of resistance that returns in these radical Italian texts, through an often explicit allegiance to postmodernism, which gets strategically but mistakenly posed as a clean break with modernism. Such an dangerously unacknowledged hypermodernism as the dominant function of postmodernism and its allegiance to the new technologies has been noted by Albert Borgmann in 'Hyperreality' as, 'postmodernism shar[ing] with modernism an unreserved allegiance to technology, but differ[ing] from modernism in giving technology a hypercomplex design' .6

I would like to underpin the above assertions by looking briefly at two thinkers, Gayatri Spivak and John Armitage, who have commented extensively on the reproduction of the discourses and technologies of Eurocentrism in both activism and academia. In 'Marginality in the Teaching Machine', Spivak discusses how the revalidation of the West and the fantasy of the Cartesian subject as the proper centre for evolution and action (whether capitalist or liberatory) relies upon the constant precarious 'reproduction of marginality'. Those who can empower themselves through this claim for marginality then have the paradoxical effect of becoming the agents of Eurocentrism, since they are a 'group susceptible to upward mobility' that function as posing as 'authentic inhabitants of the margin'. As such they seemingly prove and extend the universal applicability of the humanist subject and its technologies. ${ }^{7}$ The group-naming of an oppressed margin, or the desire to look for 'a voice' from 'refugees' or 'migrants', then taps into a modernist desire to extend its own Eurocentric belief system. This is not to say that 'naming the margin' cannot be empowering or productive-on the contrary, it is productive, but in a very specific way and within a specific exclusionary frame of thought and technological production, of which academic and activist praxes that theorise and act out 'resistance through alliances with the oppressed' are then co-constitutive.

Spivak takes this analysis further when she identifies within this need of the Cartesian subject to 'identify the margins' also a desire for (an inherently uneven) alliance with those 'margins' as a means to transcendence, which comes about through falsely imagining that one ultimately shares the same struggles and goals. The supposedly 'authentic' subversive struggles from those margins then become the paradigmatic fantasy of liberatory struggles for Eurocentric activist thought. Spivak, while discussing how in academic literary circles such an identification (in her case, with 'Third World writers') works, asks: 'How is the claim to 
marginality being negotiated here? The radicals of the industrial nations want to be the Third Word'.8 In A Critique of Postcolonial Reason, Spivak aptly calls this role of a metaphorical subaltern in service of Western hegemony the 'native informant'. 9

Spivak builds on the idea of the 'native informant' within global capitalism in the interview 'The Rest of the World' with Mary Zournazi, by explaining that the fact that (poor) people want certain technologies or want to migrate does not mean that they are not being 'forced'.10 In fact, the argument that they 'want' to migrate and that therefore technologies of travel and communication are 'good', is exactly the argument that Eurocentric neo-liberalism uses to validate itself as benevolent, even when the hierarchical premises of the technologies and discourses of capitalist production, and the identity of some migrants, do not 'match'. Spivak thus recognises that the creation of a 'general will for post-industrial finance capitalism' creates a 'coercive situation that is being disguised as an invitation',11 and I would argue that 'the migrant' in much radical Italian thought masks such moments of 'coercion' as sprouting from 'subversive free will'. Eventually, this validates a Western self-centred fantasy of being the main actor within a world-spanning form of effective resistance to global capitalism, while the very possibility of perpetuating this fantasy-a fantasy of transcendence-is made possible by global capitalism.

John Armitage provides a useful insight into how the new technologies are related to the reproduction of Eurocentrism through both their material and discursive structures, and how the figuration of the migrant as boundary breaker may be complicit in such a scheme of reproduction. In 'Resisting the Neoliberal Discourse of Technology: The Politics of Cyberculture in the Age of the Virtual Class', Armitage points out that the current mode of late capitalism relies mainly on continuously extending and legitimising both the infrastructure and the neoliberal discourse of the new information technologies. ${ }^{12}$ Discourses that get repeated in favour of the emerging global 'speed-elite', as Armitage calls it, are typically those which champion connection, liberation, multiplicity and overcoming boundaries. Such discourses, which often implicitly rely on highly technologised spaces for action and communication between allied groups, as well as on a rendition of the 'postmodern condition' as effectively a stage beyond modernism, suppress the violent colonial and patriarchal history of those technological spaces and the subsequent unevenness of any such alliance. The Eurocentric subject can only handle radical difference by incorporating it in a revised grand scheme of liberation, and the supposed neutrality or positivity of certain spaces and technologies silently reconstructs historical inequalities. The result in both radical Italian thought and alter-globalist activisms dealing with migrant issues is, as we will see, that the migrant or refugee becomes the imaginary 'ally par excellence' to serve the extension of Eurocentrism and its tools for this new speed-elite.

Much so-called 'new radical Italian thought' has been bundled together under the autonomous Italian publishing house DeriveApprodi, which recently published a booklet called 'Luoghi comuni: il movimento globale come spazio di politicizzazione' (Common Places: The 
Global Movement as a Space for Politicisation). ${ }^{13}$ In this text, which serves as a good starting point into discourses around 'the migrant', several unnamed authors seek to describe the current antiglobalisation movement and to make claims its future direction. They do this in a sincere attempt to tackle some of the modernist and imperialist logics that informed previous anticapitalist struggles. However, they end up positing 'the' anti-globalisation movement as 'an open space of politisation' whose first major cycle, which supposedly moved from Seattle to Genoa, connected the resistance struggles of the 'workers in Korea, Nigeria, Brazil, and ... in Zapatist Chiapas'.14 The global unity that anti-globalism strives for is, in their view, not even a utopian wish anymore, but already an actual reality. ${ }^{15}$

Here one can recognise, as Fran Martin puts so lucidly, 'the 'performative strategy of white, Euro-American [thought] effectively globalising marginalised categories by pronouncing them already globalised'.16 This discourse, together with the authors' anonymity, obfuscates the Eurocentric and rather self-indulgent notions of how and what kind of liberation should come about. Whose revolution then are they talking about, and how do various other local struggles get symbolically and materially appropriated in this cause? Who benefits from such an empowering discourse, and who will be excluded? It is noteworthy that Sandro Mezzadra and Fabio Raimondi, whose work I will discuss shortly, at least acknowledge in 'From Global Movement to Multitude' that the anti-globalisation movement seeks to use and enforce globalisation instead of countering it, in order to 'create a more favourable global power dissemination'. ${ }^{17}$

This larger rhetorical 'unification of struggles' under the umbrella of 'the movement' in 'Luoghi comuni', runs parallel with a particular revision of a Marxist anti-statist epistemology in Italian thought, that seems to have required a similarly revised notion of who then constitutes Spivak's 'most deserving marginal'. The problematic metaphorisation of 'migrants' (and of 'the new poor') within radical Italian thought, that serves this function of the ideal 'other', is most blatantly pervasive in the work of Sandro Mezzadra. In 'The Right to Escape', Mezzadra perhaps usefully imagines a different way of talking about migrant and refugee issues than the widespread othering and exclusion of illegal migrants, especially within the European Union, in terms of being a threat or a victim. ${ }^{18}$ He tries to problematise the constructedness of various geographical and national borders by invoking a language that looks for the possible precariousness of borders per se, and does this by redefining the notion of 'escape'. However, he simplistically claims that 'escape [is] a political category'. ${ }^{19}$ '[E]scape' is in his view supposed to be empowering because it is a 'privileged way to subjectivity, a road to freedom and independence'. Likewise, Mezzadra creates a generalised notion of 'migrant subjectivity' that is inherently revolutionary, without recognising how any migrant struggle or empowerment is historically and geographically specific. Despite his correct assertion that stereotyped representations of some EU migrants have removed 'a substantial part of the plurality of 
positions', Mezzadra ventures to depict all migrants as equally oppressed and subversive, and 'the migrant condition' as having 'paradigmatic capacities'. ${ }^{20}$

This argument, which Mezzadra also reiterates in 'Citizenship in Motion', dangerously pretends that it lets someone else speak. It is, in fact, 'Mezzadra's' imagination speaking. ${ }^{21}$ Such modernist rhetorics of 'escape' and 'freedom', enunciate the Eurocentric myth of an (white, male) all-knowing subject outside of power structures. It fails to conceive of agency as needing to work in tandem with societal forces, because it wrongly imagines victimisation as inconsistent with agency; a repetition of a typical modernist dualism. To argue, as he does, that migrants 'set out on their voyages of their own will' does not mean, as we saw with Spivak's notion of 'disguised coercion', that they are no longer victims of or subjugated within certain power structures. ${ }^{22}$ Such an assertion erases the violence and disenfranchisement that such Eurocentrism globally enacts, through upholding myths that support the gendered and raced infrastructure of the speed-elite and the upwardly mobile. This erasure of the legacy of race in global hegemonies becomes particularly clear when Mezzadra talks about 'the' migrants as having the 'leading role' at the European Social Forums, which has put 'the struggles of the last three years effectively beyond ... the antiracist character of migration initiatives', as if the Social Forums are so subversive that the issue of race has finally been overcome. ${ }^{23}$ Such a facade of a break with modernity re-enacts modernity, and is completely in line with the dominant sexist and racist discourses of neo-liberal global capitalism and meritocracy when these falsely claim that 'anyone can be economically successful as long as one is smart enough'. Similarly, Mezzadra's discourse oddly declares any migrant as privileged, when in fact the privilege of their appropriation belongs primarily to him and those others who can envisage their own crossing of borders and alliances within (virtual) spaces of communication as intrinsically progressive. On the contrary, one could argue that the construction of 'new transnational social spaces' through new communication and transportation technologies, is exactly what neo-liberalism is all about. ${ }^{24}$

This continuous underlying affirmation and repetition of the West, and the neo-liberal speed-elite, as the cradle and current centre for social change is also present in Mezzadra and Raimondi's 'From Global Movement to Multitude'. Calling the protests in Seattle and Genoa a result of 'the movement of movements' that strives for 'the unification of the planet', Mezzadra and Raimondi talk pretentiously about feelings 'of pain and joy' during and after the Genoa protests 'comparable in intensity to the feelings after $9 / 11$ '. ${ }^{25}$ They go on to claim that all kinds of past liberatory struggles, from feminist to environmentalist, are now all unified under the sign of 'the big struggle', making for instance anti-sexist activism falsely congruous with global anticapitalist activism. They problematically render the image of the new communication technologies as the one 'neutral' tool that 'all these groups so skilfully use'. Moreover, the 'body of the migrants' gets played out as the one supposedly homogeneous group that signifies the ideally required subversion of boundaries within the capitalist global system: 
The migration movement, with the elements of subjectivity they take with them, were this year really one big laboratory of the 'globalisation from below'. Under our eyes they developed a genealogy ... They create a dramatic tension between the cosmopolitan demands for freedom of movement and the insurrection of new borders. ... If the movement really wants to provide an alternative, then it should recognise in the migrant the meaning of its incentives as well as the most important form of subjectivity. 26

Many radical Italian texts and their derivatives likewise speak of 'new subjectivities', obliterating the extent to which subjectivity is not and cannot be 'new'. Instead, such supposed newness often functions under neo-liberalism as a marker of 'coolness', progress and success. In the interview 'Neither here nor elsewhere', Brett Neilson asks Sandro Mezzadra why migration has become such a prominent place of concern within the World Social Forums and subsequently within Italian thought. Tellingly, Mezzadra explains that at the G8 protests in Genoa, there was a 'large rally organised by migrants that was a big success' ${ }^{27}$ This success made them organise a topic at the European Social Forum on the critique of the European Schengen Agreements, which describe some new border policies within the $\mathrm{EU}$, in order to oppose national and European border policies 'as a matter of principle'. Mezzadra, describing how the previous victimisation of migrants within the anti-globalisation movement has been paternalistic and 'merely' resulted in assistance, care and protection, suggests that the new image of the migrant is instead one in which 'see[s] migrants as the central protagonists of current processes of global transformation'.28

This pervasive and problematic heroisation of the migrant within Italian thought can be traced back to the influential 1996 article 'Beyond Human Rights', in which Giorgio Agamben helpfully moves away from the classical notion of 'workers and human rights' upon which a lot of Marxist and liberatory thought and praxis was-and continues to be-based. However, Agamben further on claims that '[we should] build our political philosophy anew starting from the one and only figure of the refugee' because the latter fruitfully 'represents a disquieting element in the order of the Nation-State'. ${ }^{29}$ Here too, his description imagines the refugee as a crucial metaphorical breaker of (in this case national) judicial boundaries, without realising that for certain refugees the affirmation of territorial or bodily boundaries may be exactly what they need or want. Agamben thus appropriates 'the refugee' for his own Marxist fight against the capitalist state. But while it is one thing to point at the material and judicial poverty of certain migrants, it is quite another issue to build a whole politics on the hero-figure of the migrant or refugee whose particularity is lost in favour of unification strategies against 'the State' or 'capitalism'. Worse, such a strategy seems to play into the hands of those who wish to be saviours of marginality; the fantasy of somehow 'being the refugee' reproduces the material infrastructure for mobility and transcendence of the speed-elite. Indeed we can recognise, as 
Spivak noted, that 'the radicals of the industrial nation want to be the third world'. 30 Without a doubt, such a self-revelatory discourse by Mezzadra and Agamben problematically idealises the extremely mobile and flexible individual, enabled by globalisation and communication technologies, while in the meantime imagining itself as a truly subversive and liberating figure at the centre of the socio-economic realm. This fantasy resembles the actual real-life experiences of many Western academics and activists who communicate incessantly online and travel the world to demonstrate or discuss solutions to 'global problems'.

Arianna Bove and Erik Empson rightly suggest in 'The Dark Side of the Multitude', that the idea of the political subject against capitalism or the state, ${ }^{31}$ results in an emphasis on 'exodus' as the only possible solution against global dominance and falsely creates 'capital' or 'the state' as an a-historical and undifferentiated subject of oppression. ${ }^{32}$ Resistance as outside the state paves the way for a neo-humanist rhetoric which perpetuates the historically and geographically specific modes of oppression under nationalist and capitalist modes of production. ${ }^{33}$ Not surprisingly, Agamben ends his diatribe against the Nation-State and false exemplification of the refugee by arguing for the existence of several political communities within the same state but 'in exodus from each other'. He claims that this would lead to the 'European cities rediscover[ing] their ancient vocation (sic) as cities of the world'. ${ }^{34}$ Such grand nostalgia for Europe's glorious past glosses over the colonialist and patriarchal horrors done in the name of those so-called 'cities of the world'. Interestingly, this combination of Marxism and postmodern relativism is very similar to many 'radical democracy' writings-the French counterpart of radical Italian thought-like those of Ernesto Laclau and Chantal Mouffe. ${ }^{35}$ Both these schools install a humanist discourse of self-determination, not for an individual but for some completely undifferentiated kind of 'community', that is falsely posed as having both internally and as a group the very same Enlightenment capabilities, as if that community itself were a coherent Cartesian subject. One could perhaps read such an increase of theorising 'communities in exodus from each other' within recent European left-wing radical thought as a crisis-managing of the failure of the rhetoric of multiculturalism so pervasive in the 1980s, which nonetheless unwittingly repeats the flaw at the heart of multiculturalism: a forged unity through a pretence of allowing for differences.

Let us next turn to an excellent example of the pervasive romantisation of the migrant in academic and activist thought: Michael Hardt and Antonio Negri's Empire, widely claimed to be the very 'bible of the anti-globalisation movement'. ${ }^{36}$ The ambivalence of the modernist and classist presuppositions of 'the' global libertarian struggles and the postmodern attempt of describing a new internally differing and contradictory 'mass', comes together in Empire under the notion of 'the multitude', which has come to serve a similar unifying strategy within radical Italian thought. If the migrant metaphor is the individualist rendition of the fantasy of transcendence, then the multitude is its supposed 'communal hero', despite being described elsewhere by Negri as an 'irreducible multiplicity'. ${ }^{37}$ While such a conception surely seeks to 
describe the absolute differences between individuals, it constantly slips into a form of postmodern relativism in service of some globally perceived anti-capitalism. Hardt and Negri do not attend to axes of power and oppression, like sexism and racism, that traverse this 'multitude'. The term becomes a discursive fortification of the subject as Cartesian, through implicitly attesting to liberation in a totally singular way. Spivak correctly recognises in 'Revolutions That As Yet Have No Model' in such a rhetorical manoeuvre common to alterglobalist thought; an 'individualism more or less disguised as pluralism'. ${ }^{38}$

Furthermore, Hardt and Negri claim in Empire that this new world order results in the creation of a 'global proletariat'. Such a creation, they argue, unifies all subjects under late capitalism. They conflate the idea of the 'virtual' space with the notions of 'being, loving, transforming and creating that reside in the multitude', suggesting that cyberspace has made possible the supposedly liberatory desires that 'naturally' reside in 'the multitudes'. ${ }^{39}$ Such a fantasy again completely overlooks the materially violent and exclusivist histories and effects of the new technologies. But more importantly, Hardt and Negri are ignoring the question of what could possibly constitute an actually internally differing multitude which nevertheless shares the same desire for change. The reason for this essentialist assertion is that Hardt and Negri conceive of original Renaissance humanism as a system that, when 'properly' installed, will lead to a state of being in which;

$[\mathrm{N}] \mathrm{o}$ transcendental power or measure will determine the values of our world. Value will be determined only by humanity's own continuous innovation and creation. 40

Not only is this statement stunningly nostalgic and naïve, it generates a highly exclusionary and Eurocentric image of personhood as an Enlightenment subject proper, capable of-or even primarily born for-self-constitution, active creation and expression of his individual 'free will'. This kind of patriarchal essentialism serves to justify the neo-liberal rhetoric, hinging on transcendental Cartesianism, that everything and everybody should and will ultimately be 'freeflowing'. Instead, I would like to argue with Spivak and Armitage that anybody's 'free flow' in essence can only be the result of power structures. It is therefore hardly surprising that Hardt and Negri find in the mobility of migrants their ideal global subversive protagonist, when they claim in Empire that;

[T] he postcolonial hero is the one who continually transgresses territorial and racial boundaries, who destroys particularisms and points towards a common civilization. 41

This overt heroisation once more renders actual migrants and the relation of situated violence to local and global hegemonies that made them migrate, invisible. It serves once more as the rhetorical foundation for a false unification of what constitutes current lives and struggles. This is not to say that some individuals who identify as 'migrant' or 'refugee' do not occasionally make empowering use of these rhetorics. Even within certain sections of the European and 
World Social Forums, some 'upwardly mobile' migrants have cunningly done so. But such cunning points to the fact that this subject-metaphor within Italian thought is highly complicit with the institutions and technologies of subjugation available under hyper-modernism.

Furthermore, Hardt and Negri replicate the simplistic misreadings of Deleuze and Guattari's 'desiring machines' so common to North-American utopian thought. The conflation of the virtual with the desires of the multitudes, who somehow seem to long for the same thing-freedom from any constraint-ends up equating the actual Internet and its highly-polarising global economic system as a 'smooth space' for alliance and transformation, as if it were the material replication of Deleuze and Guattari's rhizome. Indeed, Hardt and Negri wrongly describe the Internet as a 'unlimited number of interconnected nodes with no central point of control ... what Deleuze and Guattari called a rhizome'.42 Similarly, they problematically transform Donna Haraway's cyborg fable ${ }^{43}$ into a purely beneficial utopian scheme. ${ }^{44}$ Michael Rustin hints at the reasons of the widespread success of Empire within the European and American alterglobalisation movement and Noborders propagates, when he concludes in 'Empire: A Postmodern Theory of Revolution' that:

The political appeal of their analysis, its natural constituency so to speak, is to those called by 'desire' in its various forms, and moved by hostility to restriction and restraint ... Global capitalism has been the bringer of this condition of freedom. 45

The irony is then that, while Hardt and Negri explicitly take a 'postmodern Marxist' position, they implicitly herald global capitalism and its technologies as the one condition which allows the multitudes to ally and liberate themselves. Hardt and Negri have no eye for either their own complicity within capitalism's neo-colonisation through the material and discursive reproduction of Eurocentrism, nor for the massive resources- and people-intensive labour such an infrastructure for the happy few requires. Tellingly, Timothy Brennan therefore calls Empire in 'The Italian Ideology', despite Hardt and Negri's erudite renditions of European theories; 'so cheery and, if one can put it this way, so American'. 46

The romantisation and the false identification with the supposedly subversive qualities of 'the migrants' attains almost grotesque forms in Hardt and Negri's sequel to Empire, called Multitude. War and Democracy in the Age of Empire. Not only do they again overlap 'networked resistances' with the 'subversive power of the multitude', they also go to great lengths to locate such subversive powers of the multitude primarily in 'the poor'. ${ }^{47}$ This is because the poor supposedly 'embody the ontological condition not only of resistance but also of productive life itself'.48 While this is already a very questionable exotic depiction, they then represent 'the migrants' as a subset of the poor, constituting, 'a special category of the poor that demonstrates this wealth and productivity' of resistance and 'life'. They continue this heroisation by opposing present-day migration to the great European migrations of the past into 'empty spaces', arguing that instead, current migrations move into 'fullness' because the 'economies need them' and 
because they themselves are 'full'. Not only do they then negate the presence of other peoples and their violent colonialist overtaking but they bestow some kind of inherently subversive subjectivity onto all migrants, while actually supporting a mode of production which foremost benefits the speed-elite. They also project onto the migrants a vague desire for 'something more, their refusal to accept the way things are', without acknowledging how 'a desire for something more' might lie exactly at the base of, for instance, capitalist corporate expansion. ${ }^{49}$

In the same way, Negri erases the potentially illuminating analysis of this constitutive relationship in his debate with Danilo Zolo. Zolo is correctly suspicious of many of Empire's rhetorics and goes as far as to say that the 'emphatic exaltations of the power of the multitude ... [appears] indebted to Marxist messianism and its grandiose political simplifications'.50 Zolo also points out that Empire seems 'animated by a real technological fervour'. Despite this, Negri thus continues his dangerous exotisations by claiming that 'the migrant has the dignity of those who searches for truth, production and happiness' and that the 'information revolution provides ... new spaces for freedom'.51 This false nostalgia is again founded on the well-intended claim, which we also saw with Mezzadra, that we must oppose the previous victimisation of the migrants and instead see them as 'actors'. But as with Mezzadra's misconception of 'escape', the repetition of the opposition of victims and agents is extremely Cartesian, and leaves no space for the urgent analysis of how agency, empowerment and subjectivity are in fact embedded in pervasive power structures.

The benefactors of such a modernist rhetoric are those who can romantically identify with such desires to be 'free' and mobile, while simultaneously imagining that they are somehow also subversive, without suffering the dire consequences of technocratic globalisation. Again, Spivak is correct in noticing that this Eurocentrism perpetuates itself in the avowal that 'the radicals of the industrial nations want to be the third world', which can also be seen in the fact that the section on migrants in Multitude is rather offensively titled 'The Wealth of the Poor (or, We Are the Poors!)'.52 I would therefore also like to suggest that such an exaltation of migration throughout both Empire and Multitude not only supports and enhances the tools and discourses of the speed-elite, but simultaneously appeals to the vanity of the Western alter-globalist reader (and writer) who imagines him- or herself at the centre of liberatory global change.

The reader of Empire and Multitude cannot help but feel that the 'multitude' and 'the migrant' are rhetorical ploys to force the various differential feminist and anti-racist struggles under the umbrella of anti-capitalism, while effectively silencing them. Indeed, the only reference to feminist theory is in the footnote in Empire that says: 'In fact ... we would say that the most profound and solid problematic that has yet been elaborated for the critique of biopolitics is found in feminist theory'.53 Though briefly mentioning Spivak's critique of the European 'workerist' schools as 'perhaps' a good way to re-evaluate their own and other anticapitalist analyses, Hardt and Negri however do not examine this point at all in Empire. 
Several other radical Italians have explored the promises and faculties of the new communication and transportation technologies. Matteo Pasquinelli, for example, exhibits a rather essentialist techno-optimism in claiming that the anti-globalisation movement should expand on the ideas of the free software movement and its basic slogan 'information wants to be free'. In a textual move that resonates with popular notion of the 'temporal autonomous zone' as the 'subversive web in the dominant net',54 Pasquinelli says that the Internet is part of a larger network of human communications that can be divided into 'good' and 'bad' collective intelligences. ${ }^{55}$ The 'good collectives' are the whole of the global movements, under which according to him fall also the free software, the academic knowledge sharing community, the Creative Commons project for art and knowledge sharing (which has a website in the US and soon also in Italy) and the 'precarious workers' movements.

Pasquinelli avoids the term 'multitudes' for this grouping, because he considers the concept 'more useful to exorcise the identitary pretences of the global movement, than as a constructive tool'.56 While I seriously doubt whether the term has indeed exorcised these pretences in any way, Pasquinelli nonetheless ends up simplifying 'the' global situation into 'radical machines versus imperial techno-monsters', through projecting both the 'good' and the 'bad' collective intelligences onto the technologically networked communication spaces. This fails to acknowledge how such discourses (and their subjects) are in fact mutually intertwined and overlapping. Pasquinelli writes himself and his fellow media-activists 'into the margins', while omitting any mention of the privilege, access and (cultural) capital possessed by individuals who meddle with new technologies have. His text serves to exorcise any potential unease over the complicity of the free software movement and of other media-activism in the violent expansion of Eurocentrism and neo-liberalism. It projects its own violence on the fantasy of 'bad collective intelligences'.

The entanglements between these romantisations of migrants and its complicit cyberhappy push for the virtualisation of communications and economics, can also be seen in the fact that much of the European and Australian Noborder activist writings, similar to Mezzadra's work, get published on the MakeWorlds website whose central theme is an internally contradictory and rather geekish phrase: 'border $=0$, location=yes'. ${ }^{57}$ Also, the Australian new media organisation and website fibreculture, which is committed to the building of a public info-structure through Internet technologies, has hosted various events around ideas of the multitude. ${ }^{58}$ MakeWorlds hosts a number of articles that equate the capacities of new technologies, in their bordercrossing and accelerating functions, with the alleviation of migratory miseries. Furthermore, a lot of these theories and Australian actions rely often explicitly on the work of several radical Italian thinkers. A good example of this is the work of Angela Mitropoulos, an activist-intellectual who has been at the cradle of the Australian NoBorder initiative xborder. In the MakeWorlds essay 'Movements against Enclosures: Virtual is Preamble', Mitropoulos suggests, through a problematic appropriation of Deleuzian's nomadism similar to the one invoked by Hardt and 
Negri (which she dubs 'techno-nomadism'), that the Internet is essentially antagonistic to 'authorised' spatial organisation, and that therefore virtual space is a precursor of a more general breaking down of or 'escape' from hierarchies and borders. Migrants' movements therefore first became visible in cyberspace, because these both invoke Deleuzian 'lines of flight and escape'.59

Continuing with an analogous set of techno-metaphors, tackles Jason Read's The MicroPolitics of Capital, in which he correctly argues that resistance under late-capitalism is interior to power.60 This of course posits the question for Mitropoulos, of what is the use of resistant practices, like migrant activism or even of critical reading and writing, when they are inevitably part of capitalist production. Seeking to recuperate Noborder activisms as nonetheless subversive in the light of the 'irreducibility' of resistance to power, Mitropoulos claims, referencing Negri's idea of the multitude as subversive, that 'crossing the border' remains a 'critical practice' because it is a physical movement instead of a result of the capitalist subjugation as 'immaterial worker'. ${ }^{61}$ Moreover, she likens the border-crossing experiences and critical writings of the Noborder groups with the displacing qualities of the internet regarding critical intellectual practice, and misses the opportunity to critically reflect on the 'conjunction between newer forms of work and communication and undocumented movement by adopting the language and topography of the net' which she correctly notices. ${ }^{62}$

The problems with such romantic recuperations in Mitropoulos' work are quite similar to those we saw with Mezzadra and Hardt and Negri. More specifically, what she fails to understand is that empowerment exists in the complicities she (and other upwardly mobile migrants) engage in, in this case through the available neo-liberal and Eurocentric imagination of depicting new technologies and their transcendence of national borders as subversive. Calling the movements of undocumented migrants 'autonomous' is therefore a gross misunderstanding of how such movements are instead extremely dependent (on available capital, infrastructure, or even good health to travel, as well as on the pull of the existence of certain borders inside of which a 'free' and safe space to work and live is guaranteed for privileged migrants). It is therefore partly incorrect that she understands the type of beliefs that circulate under postmodern production as completely irrelevant, as instead her analysis shows that it is precisely these rhetorics of mobility, technological progress and transcendence that are increasingly the dominant myths available for resistant imagination. ${ }^{63}$ Similarly, she applauds the alliances between 'immaterial workers' and 'illegal immigrants' in the xborder practices, while failing to notice how such an alliance is a hierarchical product of late-capitalism. All in all, this is not to say that all these initiatives around 'erasing borders' may not be well intended, but that these intentions are much more complicit in the spread of Eurocentric globalisation.

The paradoxical expansion of the spaces and tools of the speed-elite through the rendition of refugees and migrants as 'most oppressed' and as subversive signs of border crossing, returns in the actual practices of many Western alter-globalist groups that deal with migrant issues. 
Many of these activisms are indeed suspiciously in tune with cyberhappy new media rhetorics of supposed unhierarchical networking, free flows and transnationalism, like for instance the name Free Flooding already suggests. These groups also physically use the Internet as a main tool for communication and alliance building under the false pretence of it rendering an 'open space'. The well-intentioned NoBorders network website is full of discourses of mobility and breaking down borders, without recognising that it is the very constraints that make an empowering function like media activism or citizenship, which migrants or refugees may desire, possible in the first place. The simplistic modernist myth of freedom versus constraint returns with devastating effects in certain NoBorder practices, when, for instance, in Europe, the group helped refugees to escape from a detention centre, after which they had to turn themselves in again because their 'liberators' had not thought of what to do next, after that wonderful utopian 'setting them free'. The 'freedom' of being outside of legislation and unrecognised by borders is, as many refugees may be able to tell you, not really desireable.

Another such instance of how such activisms turn out to be detrimental for some of the actual migrants involved, are the 'civil disobedience' actions around the former Australian detention centre Woomera. In the Easter of 2002, a large caravan of activists, complete with their improvised Indymedia centre, gathered for a number of protest rallies at Woomera. During one of the protests, several detainees managed to get out of the confinement by climbing over the barbed-wire fences while the activists were chanting 'freedom, freedom'. ${ }^{64}$ The outbreak was depicted in highly emotional terms by the activists who said that the detainees were 'crying for freedom' and that a number 'reached out to touch our hands.' Such stories make obvious the huge investment of desire in the idea of 'freeing' the detainees. One of the participants, Kanthi Lewis, tellingly wrote that they were 'making the journey [to Woomera] to discover our humanity in the liberation of those who have been dehumanised', which shows how the caravan also worked as a form of redemption and reinstallation of the modernist idea of 'liberation' for the participants. Also, virtually none of the currently circulated stories on Woomera2002 is told by the (ex-)detainees themselves, but there exists instead a plethora of activist impressions online. Most end with emotional accounts of that day but do not go into what happened with the detainees afterwards. Furthermore, a striking aspect of these stories is that they are told by enunciating a very strong 'we' (the helpers) versus 'they' (the victims) opposition. 65 Again, as in the European case, none of the activists had thought of what to do after the refugees escaped from the camp. In the months that followed, the Australian government decided to close Woomera and transport all the detainees to the high-tech surveillance Baxter detention centre, as well as to off-shore camps. So much for improving the lot of the detainees. Mitropoulos mentions on Indymedia Sydney that the civil disobedience action was 'audacious, but ... impractical', but does not go into details nor reflect on what urged the activists to read the misery of the crying detainees as a 'cry for freedom' that could simply be obtained by 'helping them out' in this way.66 This does not mean that refugee detention centres are not highly 
problematic institutions in which people often live in horrible conditions, but that a simple destruction of fences, or an elimination or traversing borders in general, as always liberating is misguided-on the contrary, many of the (new) refugees were perhaps worse off after the action.

There exists no proper analysis in such Noborder activisms of how 'we' can live in luxury, cross certain borders, and enjoy new technologies because 'they' can (partly) not. The increasingly widening gap between rich and poor, the ongoing feminisation of poverty, and the disenfranchisement of certain people worldwide, which makes some of them migrate in search for a better life (if they have the initial privilege to do so), is a result of exactly those humanist desires for more 'freedom' that lie at the base of late-capitalist globalisation and technological innovation. Furthermore, Noborder activism fails to see how discourses of migration and mobility work in tandem with the increasing neo-liberalisation in favour of the speed-elite, through using and promoting new technologies as tools that transgress borders. Indeed, Mitropoulos mentions that the Internet is of main importance to the NoBorder and xborder actions, without realising the connections between the mode of production that surrounds the Internet and the increasing implementation of high-tech surveillance gear around camps like Baxter.67 Mitropoulos draws on the work of Hardt and Negri to falsely conclude that 'crossing the border is a permanent condition of critical practice'.68 These NoBorder examples thus show that the activist's and the activist-academic's desires or fantasies to break with or overcome certain power structures is structurally situated within those very spaces of power, and therefore in effect always silently reproduces the hierarchies it hopes to contest. In the end, empowerment and subjectivity are produced by power structures, and while every repetition of structures surely always also suggests difference, any discourse of successfully and intentionally effectuating difference and overcoming sameness (of power structures) can in the end only be a dangerously masked repetition of the same.

To conclude, the current obsession in so-called 'radical Italian thought', as well as within the alter-globalisation movement and in academic and policy-making institutions, with 'the migrant' or 'the refugee', points at a peculiar new mode of production of 'the most deserving marginal' in the West, to use Spivak's words. While many policy institutions tend to depict the migrant (and of course, only the migrant from certain regions, or with certain skin colour or religious beliefs) as a problem or object, the image is rendered into a symbol of resistance or subversion in much Italian 'radical' writing, much like the notion of the hybrid or nomad today gets decontextualised and appropriated in a lot of activist and academic thought. We can conclude that the romanticised rendition in radical Italian thought of the migrant or refugee as boundary breaker is a dangerous falsification serving the transcendental and self-valorising fantasies of those who already are the 'winners' in the global hegemonic power struggle, and can afford to take up a position as 'saviours of marginality'. Because ultimately, it is not national or judicial borders that migrants or refugees inherently contest; on the contrary, migrants in fact 
attest to such borders by their very existence as partial outsider while simultaneously being detained within those borders which then reproduce themselves around those refugees.

Moreover, migrants usually make obvious the empowerments through those borders by actively 'wanting to be subjugated within them', or in other words by seeking to obtain that much-needed sovereign citizen status within either their previous or those new national borders, in order to gain possible access to speed-elite status. Rather than being some authentic resistant force that precedes or subverts the emergence of national or bodily borders, the refugee or migrant is an effect-both 'victim' and 'agent' within complex and heterogeneous sets of power structures-of the discursive and material violence of national borders as these seek to (re)structure and re-inscribe their internal and peripheral boundaries and laws. Any politics that constructs the migrant as some sort of subversive hero, not only romantically reproduces the fantasy of sovereignty but more seriously obscures the violent sexist and racist history and present of those material and technological conditions that make such a modernist appropriation possible in the first place. Ryan Bishop and John Phillips call this appropriation,'the hallucination of radical alterity', which functions in service of the new global speed-elite.69 This results in a material strengthening of Western hegemony through the exponential use of technologies of mobility, connection, and border-crossing desired by this elite, eventually enforcing and spreading Eurocentric modernist myths of like 'freedom' and 'transcendence from constraints'. And it was and is exactly from the often violent militaristic, technological and material reinscription and expansion of such modernist and neo-colonialist discourses, that many refugees suffer.

Ingrid Maria Hoofd is a PhD candidate at the National University of Singapore. Her dissertation involves a feminist analysis of the intersections of new technologies, activism and academia in a Western context. She wrote her master's thesis on cyberfeminism at Women's Studies in the Humanities at Utrecht University, the Netherlands. 
7 Spivak, 'Marginality in the Teaching Machine', p. 59.

${ }^{8}$ Spivak, 'Marginality in the Teaching Machine', p. 57.

${ }^{9}$ Spivak, A Critique of Postcolonial Reason.

10 Gayatri Chakravorty Spivak and Mary Zournazi, 'The Rest of the World', in Mary Zournazi (ed.), Hope: New

Philosophies for Change, Routledge, New York, 2002.

${ }^{11}$ Spivak and Zournazi, pp. 179 and 176.

12 John Armitage, 'Resisting the Neoliberal Discourse of Technology: The Politics of Cyberculture in the Age of the Virtual Class', in CTheory.net, 1999, <http://www.ctheory.net/printer.asp?id=111>.

13 Derive Approdi, 'Luoghi comuni: il movimento globale come spazio di politicizzazione', DeriveApprodi, Rome, 2003.

14 Approdi, p. 22.

15 Approdi, p. 24.

16 Fran Martin, 'Dismembering Theory: Working Notes', in Dept. of English at NCU Taiwan website, 2004, <http://www.ncu.edu.tw/ eng/journal/journal_park12.htm>, p. 2.

17 Sandro Mezzadra and Fabio Raimondi, 'Van Mondiale Beweging naar Multitude', in Globalinfo, 2002

<http://www.globalinfo.nl/article/articleprint/17/-1/1/>, p. 2.

18 Sandro Mezzadra, 'The Right to Escape', in Ephemera: Theory of the Multitude, vol. 4, no. 3, 2004,

<http://www.ephemeraweb.org/journal/4-3/4-3mezzadra.pdf>.

19 Mezzadra, 'The Right to Escape', p. 267.

20 Mezzadra, 'The Right to Escape', pp. 268-9.

21 Sandro Mezzadra, 'Citizenship in Motion', in MakeWorlds, 2004, <http://www.makeworlds.org/node/83>.

22 Mezzadra, 'The Right to Escape', p. 271.

23 Mezzadra, 'The Right to Escape', p. 269.

24 Mezzadra, 'The Right to Escape', p. 272.

25 Mezzadra and Raimondi, pp. 2 and 1.

26 Mezzadra and Raimondi, pp. 2 and 4.

27 Brett Neilson, 'Neither Here or Elsewhere: Interview with Sandro Mezzadra', in Neuro-networking Europe, 2003, <http://www.makeworlds.org/book/view/17>, p. 1.

28 Neilson, p. 4.

${ }^{29}$ Giorgio Agamben, 'Beyond Human Rights', in Paolo Virno and Michael Hardt (eds), Radical Thought in Italy: A Potential Politics, University of Minnesota Press, Minneapolis, 1996, pp. 159 and 161.

30 Spivak, 'Marginality in the Teaching Machine', p. 57.

${ }^{31}$ A good example of this would be Paolo Virno, 'Virtuosity and Revolution: The Political Theory of Exodus', in Virno and Hardt (eds), Radical Thought in Italy.

32 Arianna Bove and Erik Empson, 'The Dark Side of the Multitude', in Neuro-networking Europe, 2003, <http://www.makeworlds.org/book/view/36>.

33 Bove and Empson do admit that 'in this framework ... some powerful struggles of re-appropriation do take place'. See 'The Dark Side of the Multitude', p. 1.

34 Agamben, p. 164.

35 Chantal Mouffe, 'Radical Democracy or Liberal Democracy?', in David Trend (ed.), Radical Democracy: Identity, Citizenship, and the State, Routledge, New York, 1996.

36 Michael Hardt and Antonio Negri, Empire, Harvard University Press, Cambridge Mass., 2000.

37 Antonio Negri, 'M as in ...', in Negri on Negri: Antonio Negri in Conversation with Anne Dufourmantelle, Routledge, London, 2004, p. 111.

38 Gayatri Chakravorty Spivak, 'Revolutions That As Yet Have No Model', in Donna Landry and Gerald MacLean (eds), The Spivak Reader: Selected Works of Gayatri Chakravorty Spivak, Routledge, New York, 1996, p. 101.

${ }^{39}$ Hardt and Negri, p. 357.

40 Hardt and Negri, p. 356.

41 Hardt and Negri, p. 363.

42 Hardt and Negri, p. 299.

43 For Haraway's own more ambiguous conception of the cyborg, see 'A Cyborg Manifesto: Science, Technology and Socialist-Feminism in the Late Twentieth Century', in Simians, Cyborgs and Women: The Reinvention of Nature,

Routledge, New York, 1991.

${ }^{44}$ Hardt and Negri, p. 218.

45 Michael Rustin, 'Empire: A Postmodern Theory of Revolution', in Gopal Balakrishnan (ed.), Debating Empire, London, Verso, 2003, p. 9.

46 Timothy Brennan, 'The Italian Ideology', in Gopal Balakrishnan, p. 99. 
47 Michael Hardt and Antonio Negri, Multitude: War and Democracy in the Age of Empire, New York, Penguin Press, 2004, pp. 85-9.

48 Hardt and Negri, Multitude, p. 133.

${ }^{49}$ Hardt and Negri, Multitude, p. 133.

${ }^{50}$ Antonio Negri and Danilo Zolo, 'Empire and the Multitude: A Dialogue on the New Order of Globalisation', generation-online, 2002, <http://www.generation-online.org/t/empiremultitude.htm>, p. 11.

51 Negri and Zolo, 'Empire and the Multitude', pp. 12, 11.

52 Hardt and Negri, Multitude, p. 129.

53 Hardt and Negri, Empire, p. 422, note 17.

54 Hakim Bey, The Temporary Autonomous Zone: Ontological Anarchy, Poetic Terrorism, Autonomedia, New York, 1991.

55 Matteo Pasquinelli, 'Radical Machines against the Techno-empire', rekombinant.org, 2004,

<http://www.rekombinant.org/article.php?sid=2264>, p. 1.

56 Pasquinelli, p. 2.

57 All these terms are implicit references to computer jargon: 'makeworlds' is a UNIX command, and 'border=0' is hypertext markup.

58 See <http://www.fibreculture.org>.

${ }^{59}$ Angela Mitropoulos, 'Movements against the Enclosures: Virtual is Preamble', MakeWorlds, 2004,

$<$ http://www.makeworlds.org/node/133>, pp. 1-2.

60 Angela Mitropoulos, 'The Micro-physics of Theoretical Production and Border Crossings', borderlands, vol. 3 no. 2 , 2004, <http://www.borderlandsejournal.adelaide.edu.au/vol3no2_2004/mitropoulos_microphysics.htm>

61 Mitropoulos, pp. 2 and 6.

62 Mitropoulos, pp. 5 and 1.

63 Mitropoulos, p. 3.

${ }^{64}$ Kanthi Lewis, 'Civil Disobedience and Woomera', in UTS website, 2005,

$<$ http://www.international.activism.uts.edu.au/conferences/civildis/lewis.html>.

65 See, for instance, <http://library.sievxmemorial.org/agoddard001.htm>, <http://amsterdam.nettime.org/ListsArchives/nettime-bold-0204/msg00106.html>, <http://archives.econ.utah.edu/archives/aut-op-

sy/2002m04/msg00016.htm> and many more.

66 Angela Mitropoulos, 'FOH Update', Indymedia Sydney, 2004,

$<$ http://sydney.indymedia.org/front.php3?article_id=41985>.

67 Mitropoulos, 'FOH Update'.

68 Mitropoulos, 'The Micro-physics of Theoretical Production and Border Crossings', p. 6.

${ }^{69}$ Ryan Bishop and John Phillips, 'Diasporic Communities and Identity Politics: Containing the Political', in Robbie Goh and Shawn Wong (eds), Asian Diasporas. Cultures, Identities, Representations, Hong Kong University Press, Hong Kong, 2004, p. 170. 